\title{
Employment effects and renewable energy policies: applying input-output methodology to Portugal
}

\section{P. Pereira da Silva*}

Faculty of Economics of the University of Coimbra, Av Dias da Silva, 165, 3004-512 Coimbra, Portugal and

INESC Coimbra, Rua Antero de Quental, 199, 3030-030 Coimbra, Portugal

E-mail: patsilva@fe.uc.pt

*Corresponding author

\section{Oliveira}

INESC Coimbra, Rua Antero de Quental, 199, 3030-030 Coimbra, Portugal

and

ISCAC, Quinta Agrícola, Bencanta, 3040-316 Coimbra, Portugal

E-mail: coliv@inescc.pt

\section{Coelho}

INESC Coimbra, Rua Antero de Quental, 199, 3030-030 Coimbra, Portugal

and

Department of Electrical Engineering, ISEC,

Rua Pedro Nunes, Quinta da Nora, 3030-199, Coimbra, Portugal

E-mail: dcoelho@isec.pt

\begin{abstract}
Renewable energy is playing an increasing role in energy mixes around the world, including Europe, which is aiming for a target of $20 \%$ renewable energy by 2020 . Portugal is at the forefront of the European intention, with a $31 \%$ target. The advantages of the application of renewable energy policies are widely accepted to include a decrease in greenhouse gas emissions and an improvement in energy security. In many cases job creation is also touted as a benefit but this claim stands on an uncertain footing. Amongst the variety of methodologies, analytical studies using extensive surveys seem to be more appropriate for regional studies while linear simulations, either in the form of input-output (I-O) analysis or, in recent years, social accounting matrix (SAM) multiplier analysis appear to better suit national and international studies. This paper offers an assessment of the impact of Portuguese 'green' energy policies on the employment level departing from a system of symmetric input-output tables recently built for Portugal by the Department of Foresight and Planning.
\end{abstract}

Keywords: employment; renewable energy sources; input-output tables. 
Reference to this paper should be made as follows: da Silva, P.P., Oliveira, C. and Coelho, D. (2013) 'Employment effects and renewable energy policies: applying input-output methodology to Portugal', Int. J. Public Policy, Vol. 9, No. 3, pp.147-166.

Biographical notes: P. Pereira da Silva holds a $\mathrm{PhD}$ in Finance and a Master degree in Business Administration from the University of Coimbra. She is a Professor at the Faculty of Economics, University of Coimbra (Portugal). Her research interests, conducted at INESCC, are in the areas of energy economics, energy markets and sustainable energy systems.

C. Oliveira holds a $\mathrm{PhD}$ in Electrical and Computers Engineering (Systems Optimization), a Master degree in Information Management (Management Science) and a BSc in Economics from the University of Coimbra. She is a Professor at ISCAC Business School, Polytechnic Institute of Coimbra. Her research interests, conducted at INESCC, are in the areas of economy energy - environment modelling, input-output analysis, multi-objective linear programming (MOLP) and MOLP uncertainty handling techniques.

D. Coelho holds a PhD in the area of energy systems and a Master's degree in Electrical Engineering from the University of Coimbra. She is a Professor at the College of Engineering, Polytechnic Institute of Coimbra. Her research interests, conducted at INESCC, are in the areas of energy planning, energy efficiency and sustainable development.

This paper is a revised and expanded version of a paper entitled 'Employment effects and renewable energy policies: applying input-output methodology to Portugal' presented' at 14th Annual Conference of the International Network for Economic Research (INFER), Coimbra, Portugal, May 2012.

\section{Introduction}

Creating new jobs and restraining unemployment are in the current economic conjuncture increasingly considered as crucial, namely in European countries facing severe current economic recession such as Portugal with an unemployment rate of $14 \%$ in the fourth quarter of 2011 (INE, 2012). In this context, OECD has suggested that investing in green activities has significant job creation potential (OECD, 2011). Also, UNEP (2011) has argued that "the greening of economies is not generally a drag on growth but rather a new engine of growth; that it is a net generator of decent jobs, and that it is also a vital strategy for the elimination of persistent poverty".

A number of papers have analysed in a non-detailed generic manner the contribution of renewables to socioeconomic development and to the reduction of environmental problems in several countries or regions, but the Portuguese reality has, to our knowledge, ever been studied (Henriques and Silva, 2011).

Nonetheless some authors have claimed that the potential is overestimated and environmental policies may have much less attractive labour market consequences (e.g., Morriss et al., 2009). Michaels and Murphy (2009) argue that "it is highly questionable whether a government campaign to spur 'green jobs' would have net economic benefits." Hughes (2011) has written about the 'myth' of green jobs, arguing additionally that job creation has no merit as a basis for judging policy. Policies to promote 'green' jobs have even been alleged to be "terribly economically counterproductive" (Alvarez et al., 2010). 
Consequently, employment effects and green energy policies call for more concrete applied research. With this study we aim to contribute to this discussion using the input-output (I-O) modeling approach with Portuguese data.

Traditional methods applied in jobs and economic impact analysis have mostly relied on I-O models to estimate employment creation or loss. These models measure how changes in demand for specific goods and services affect economic activity and jobs within the specific area of study (Leontief, 1985). I-O tables find use in a variety of economic analyses, especially for disaggregated modeling activities and can be combined with other databases and satellite systems, providing the framework for determining the number of jobs created.

Many countries compile I-O tables for their economies at regular time intervals both as a national statistical requirement and for the purpose of providing detailed databases for policy analysis. The basic structure of I-O-based models allows the representation of each sector's production process through a vector of structural coefficients that describes the relationship between the intermediate inputs consumed in the production process and the total output. The supply side is split into several processing industries that deliver their total output (production) for intermediate consumption or final demand (UNEP, 2011).

The analysis herein conducted relies on the Portuguese I-O symmetric tables produced by the Department of Foresight and Planning (DFP) for the year 2008 (Dias and Domingos, 2011), the latest available on December 2011. Relative employment multipliers are computed and an analysis of these employment multipliers is performed. The I-O symmetric tables have been adjusted through the use of coefficient vectors disaggregation of the renewable energy sector (RES) industry.

Thus, the present analysis provides a quantitative analysis of the employment in the Portuguese environmental industry, through the use of employment multipliers.

In the next section the concept of 'green' jobs is discussed and the modeling approach is briefly explained. Section 3 gives details of the survey and data herein used. Section 4 contains a careful analysis of gross employment in the base year and until 2020. The net economic effects are discussed in Section 5 and Section 6 concludes with some final remarks and future work.

\section{Coupling renewable energy policy and job creation}

\section{1 'Green' jobs concept}

There is no unique definition for 'green' jobs in scientific literature, making it hard to compare studies of 'green' job creation and leading some researchers to avoid its use completely. However, in a relaxed sense, 'green' jobs can be regarded as those associated with environmental objectives and policies.

Some definitions of 'green' jobs or related concepts focus on occupations and skills with an identifiable environmental focus, but most focus on employment in industries (or specific projects) the products of which are deemed to be of environmental benefit. Such benefits can be defined more or less broadly - for example, some concentrate on renewable energy, including or excluding biofuels, while others also include environmental services and/or employment related to improving energy efficiency or developing less carbon intensive products (e.g., building railways). 
In this study, we follow UNEP's definition that attempts to incorporate aspects of job content as well as the characteristics of industry goods and services. It defines 'green' jobs as "work in agricultural, manufacturing, research and development (R\&D), administrative, and service activities that contribute substantially to preserving or restoring environmental quality. Specifically, but not exclusively, this includes jobs that help to protect ecosystems and biodiversity; reduce energy, materials, and water consumption through high-efficiency strategies; de-carbonize the economy; and minimize or altogether avoid generation of all forms of waste and pollution".

\subsection{Brief chronological analysis of 'green job' creation support policies}

The Portuguese electricity market restructure process has followed a similar methodology relative to most EU countries. This typically started allowing the entry of independent power producers with long-term contracts, followed by the creation of the wholesale market, and the opening of the retail market to competition.

Thus, Portuguese energy policy framework stems from Europe's current policy and strategy for the support of renewable energy.

Back in 1997, the European Commission presented the White Paper 'for a Community Strategy and Action Plan' entitled 'Energy for the future: renewable sources of energy' (EC, 1997).

Later on, during 2001, under the policies and recommendation of the White Paper, the European Union approved Directive 2001/77/CE of the European Parliament and of the Council on the promotion of electricity produced from renewable energy sources in the internal electricity market. Already at its origin, the directive states that, beyond its environmental objective, the proposal 'can also create local employment'. That same year the Monitoring and Modeling Initiative on Targets for Renewable Energy (MITRE) project was set out by the European Commission "to confirm the view that the European Union renewable energy targets [were] achievable, and to inform key policy and decision makers of the economic (employment) benefits of a proactive renewable strategy in order to meet the targets."

On 10 January 10 2007, the Commission presented an energy and climate policy package. At the European summit in March 2007, an agreement was adopted mandating certain EU-wide binding targets that the Commission would attempt to implement, to achieve $20 \%$ of total energy consumption in the European Union by 2020. In November of the same year the Commission released its 'Strategic energy technology plan' and in January of 2008 the Commission proposed a directive that included objectives for each country, so that the common goal of the plan could be reached (EC, 2008, 2009, 2011).

According to the new directive, each member state must implement its own share of renewable energy so that the European Union can achieve, by 2020, the goal of going from a total of $8.5 \%$ (in 2005) renewable energy to $20 \%$. Each country of the Union thereby promised to increase its share of renewable energy production by at least $5.5 \%$ from 2005 levels, calculating the rest of the increase based on gross domestic product. Portugal's objective was more ambitious and was set by the government at the time to be of $31 \%$ by 2020 .

As summarised in a previous work, Amorim et al. (2010) show that the recognition of Directive 2001/77/EC set the minimum target of $39 \%$ of renewable electricity in final consumption, in Portugal, by 2011. In 2007, the government re-set it to $45 \%$ by 2010 and a year later advanced the possibility to reach the $60 \%$ target by 2020 . In $2009,45.9 \%$ of 
all electricity consumption already originated from renewable sources (DGEG, 2009) and the government intention is to duplicate renewable installed capacity within the following decade (Government XVIII, 2009). For that, specific targets have been set to be achieved by each renewable specific technology. Table 1 resumes the Portuguese renewable power capacity goals by 2020 .

Table 1 National technology road-map for installed capacity in renewable electricity sector in 2010 and in 2020

\begin{tabular}{lccc}
\hline Technology & $\begin{array}{c}2010 \text { targets } \\
{[M W]}\end{array}$ & $\begin{array}{c}2010 \text { targets } \\
{[M W]}\end{array}$ & $\begin{array}{c}2020 \text { targets } \\
{[M W]}\end{array}$ \\
\hline Wind & 3,750 & $5,100(2012)$ & 8,500 \\
Biomass & 150 & 250 & \\
RSU & 130 & 100 & \\
Biogas & 50 & 100 & 250 \\
Waves & 50 & & $1,500^{*}$ \\
Solar & & 150 & $250 * *$ \\
Geothermal & 5,000 & 35 & 7,000 \\
Large hydro & & 5,575 & 750 \\
(>10 MW) & 400 & & $60 \%$ \\
Small hydro & & & MEI 2008 \\
$(<10$ MW) & $39 \%$ & RCM n $169 / 2005$ & Prg. Gov. XVII \\
\hline Overall RES-E & RCM n ${ }^{\circ} 63 / 2003$ & & \\
\hline Sources & & & \\
& & & \\
\hline
\end{tabular}

Notes: *includes solar PV, CSP, thin film and solar thermal

** includes thermal power.

Targets include mainland and Azores and Madeira archipelagos.

\section{Evaluating RES job creation}

The literature on RES usually mentions their socioeconomic and environmental advantages. However, the analysis of the socioeconomic benefits has been rather general. Contrasting to the wider proliferations of studies focusing on the environmental benefits, the socioeconomic gains of RES have only been generally dealt with except, perhaps, the employment benefits and the reduction on the imports of fossil-fuel energy sources it brings (del Rio and Burguillo, 2008).

As previously mentioned, studies can be found, both in the European and the US contexts, indicating that employment impacts of renewable energy deployment generally observes a positive effect. In general, the employment benefits of renewables occur in the agricultural and industrial sectors and can be classified in two groups: direct and indirect. The first group generally includes taxes on property, revenues for land owners, short-term benefits (linked to employment creation in local sales and construction) and permanent benefits [operation and maintenance (O\&M) employment]. On the other hand, indirect effects might be greater than the direct effects, but are more difficult to calculate. 
Some studies only consider jobs directly created by the policies (direct employment effects) while others include jobs created in the supply chain for the products and services supported by RES policies (indirect employment effects). Kammen at al. (2004) and Wei et al. (2010) review several studies that estimate direct employment effects of promoting renewable and other low-carbon energy supply and energy efficiency, focusing on the specific labour requirements of particular technologies ('bottom up' estimates, using simple spreadsheet-based analytical models in conjunction with engineering estimates). An important issue that usually arises is the timing and duration of job creation, although not accounted for in the present study. A key distinction emerges between construction, manufacture and installation, where jobs may be relatively short-lived, on the one hand and ongoing operation, maintenance and fuel processing on the other, where the length of jobs depends on the durability of the relevant plant.

\section{The modeling approach}

\subsection{I-O methodology}

I-O methods offer the ability to model impacts of a sector on all the other sectors of an economy and are typically used for determining the economic impacts of a particular investment or activity. Using the I-O method it is also possible to analyse the employment impacts across the economy by increasing or reducing demand in a particular sector. Such examples include international or national estimates of employment (such as Caldés et al., 2009; Lehr et al., 2008). Usually, a coefficient (also known as a multiplier) is used to describe the relationship between output, employment and income of one sector on other sectors of the economy.

Studies analysing the impact of sustainable development on employment can be broadly categorised into two main categories: I-O methods and analytical methods, both with their own distinct advantages and disadvantages.

The basic structure of I-O-based models allows the representation of each sector's production process through a vector of structural coefficients that describes the relationship between the intermediate inputs consumed in the production process and the total output (Leontief, 1986). The supply side is split into several processing industries that deliver their total output (production), for intermediate consumption or final demand. These relationships can be illustrated through the following equation 1:

$$
x_{i}=\sum_{j=1}^{n} x_{i j}+y_{i}
$$

where $x_{i}$ is the output of sector $i, x_{i j}$ is the input from sector $i$ to sector $j$, and $y_{i}$ is the total final demand for sector $i$.

The level of output or the number of workers in each sector can easily measure the direct contribution of an industry in terms of output or employment, respectively. Since the employment to output ratio is given for each sector in an I-O table, the overall significance and contribution of an industry to total employment can also be calculated by assuming that the sectorial employment ratios are fixed.

Considering the hypothesis of constant returns to scale, equation (1) becomes: 


$$
x_{i}=\sum_{j=1}^{n} a_{i j} x_{j}+y_{i}
$$

in which the coefficients $a_{i j}$ are the amount of input delivered by sector $i$ to sector $j$ per unit of sector's j output, known as technological coefficients (or direct coefficients). The productive system at a national level can then be represented through the following basic I-O system of equations:

$$
x=A x+y
$$

where $A$ is a matrix of technological coefficients, $y$ is a vector of final demand, and $x$ is a vector of the corresponding outputs.

In order to finally calculate the output multipliers, one needs to derive Leontief inverse matrices. Equation (3) can then be rearranged to:

$$
A x+y=I x \Leftrightarrow I x-A x=y \Leftrightarrow(I-A) x=y \Leftrightarrow x=(I-A)-1 y,
$$

where $I$ is the identity matrix with convenient dimensions and $(I-A)-1$ is also known as the Leontief inverse. Each generic element, $b_{i j}$, of $(I-A)-1$ represents the total amount directly and indirectly needed of good or service $i$ to deliver a unit of final demand of good or service $j$ (Duchin and Steenge, 1999; Miller and Blair, 1985). In fact, the Leontief inverse indicates the direct and indirect requirements of production that are needed to satisfy a particular final demand vector (Gay and Proops, 1993). Hence, this matrix is also known as the multiplier matrix (Ciaschini, 1988).

Thus, the indirect contribution of an industry to either total output or employment is not simply observable unless the multiplier and flow-on effects are taken into account.

The share of a particular industry in total employment reveals only the direct contribution of a particular industry and this naive measure overlooks the number of jobs generated indirectly in other sectors as a result of stimulating economic activity in the industry concerned.

In summary, multipliers measure the response of the economy to a change in demand or production. Multiplier analysis generally focuses on the effects of exogenous changes on: output of the sectors in the economy, income earned by households because of the new outputs, and employment (in physical terms) that is expected to be generated because of the new outputs. The notion of multipliers rests upon the difference between the initial effect of an exogenous change (final demand) and the total effects of a change.

Direct effects measure the response for a given industry given a change in final demand for that same industry. Indirect effects represent the response by all local industries from a change in final demand for a specific industry. Induced effects represent the response by all local industries caused by increased (decreased) expenditures of new household income and inter-industrial transfers generated (lost) from the direct and indirect effects of the change in final demand for a specific industry. The total effect is the sum of the direct, indirect, and induced effects.

\subsection{Computing employment multipliers}

Based on the I- 0 tables for the year 2008 one can straightforwardly compute employment multipliers for the different RES industries. As an extension of output multipliers, employment multipliers show the employment that is cumulatively (directly and 
indirectly) used in the production process by an additional unit of output. As a result, employment multipliers help in describing the labour use in a given economy.

\subsubsection{Direct employment effects}

The estimation of direct employment in physical terms is usually performed using purely financial data on the distribution of costs among various activities for each renewable energy technology and exploiting the I-O table of the economy in question. Specifically, the analysis focuses on

a the investment costs which are composed by the cost of equipment, the cost of civil works, the cost of mechanical support, the cost of transport, etc.

b the operational and maintenance costs which are basically composed by labour costs, financial and other services, as well as by machinery and devices.

Each cost category is assigned to a number of distinct economic sectors that are included in the I-O table, which are characterised by the following two indices: total production, $P_{j}$ and total employment, $E_{j}$. Hence, it is assumed that the marginal growth $M P_{j}$ in the activity of sector $j$ caused by the realisation and operation of the RES project incurs an analogous increase in the level of direct employment $M E_{j}$ that can be approximated by the following simple equation (Tourkolias and Mirasgedis, 2011):

$$
M E_{j}=M P_{j} \cdot \frac{E_{j}}{P_{j}}
$$

It is clear that total direct employment caused by the realisation of a RES project results as the sum of all marginal increases in the activities involved in the construction and operation of the RES power unit under consideration. As expected, the largest share of the total investment cost of RES technologies refers to the cost of equipment. Thus, in order to estimate the local or national economic impacts of the RES development in a region or country, one has to take into account to what extent the production of the equipment (and thus the relative expenditures) occurs inside the economy or they are imported from abroad. In the latter case the analysis should be based only on this part of the expenditures that are spent inside the economy in question.

\subsubsection{Indirect and induced employment effects}

Through the exploitation of I-O analysis both indirect and induced employment effects associated with RES utilisation are estimated. Knowing the sectoral employment of the economy under consideration, the Leontief inverse matrix can be used to estimate the total employment effects of a policy or investment, through employment multipliers. The employment multipliers measure the total change in employment resulting from an initial change in employment as a result of the change in the output of one or more economic sectors.

As already mentioned, two types of multiplier could be estimated (Tourkolias and Mirasgedis, 2011).

The Type I employment multiplier is the ratio of direct plus indirect employment change to the direct employment change: 


$$
W_{j}=\sum_{i=1}^{n} \frac{\left(e_{i}\right) b_{i j}}{e_{j}}
$$

where $W_{j}$ is the Type I employment multiplier for sector $j, e_{i}$ (or $e_{j}$ ) is the employment per $1 €$ of total output per sector and $b_{i j}$ is the Type I Leontief coefficient identifying the direct and indirect effects on the demand for the output of industry $i$ as a result of changes in the demand of industry $j$.

Similarly, the Type II employment multiplier $\left(W^{\prime} j\right)$ measures the ratio of direct, indirect and induced employment change to the direct employment change:

$$
W_{j}^{\prime}=\sum_{i=1}^{n+1} \frac{\left(e_{i}\right) b_{i j}^{\prime}}{e_{j}}
$$

where $b_{i j}^{\prime}$ is the Type II Leontief coefficient.

Because the purpose of this type II Leontief multiplier is also to estimate the flows of money in and out of households and the effect of these transactions upon industries (i.e., the induced effect), it is necessary to 'endogenise the household sector'. This consists on treating households as an additional industry by adding an extra row and column into the direct requirements table for 'compensation of employees' and 'household expenditures' coefficients respectively.

\section{Implementation of methodology in Portugal}

The I-O symmetrical product by product tables for total flows at basic prices at current prices of 2008 herein used were produced by the Portuguese DFP and consist of 64 production sectors (Dias and Domingos, 2011).

The most straightforward way to assess employment effects is to collect employment data directly from the units involved in the considered activities. However, in most countries, such as Portugal, the number of other related RES activities are still few and reliable data regarding employment inputs are either scarce, missing or vary significantly from case to case. Therefore, the estimation of direct and indirect employment in physical terms was performed using assumptions based on several sources. The total level of full time employment equivalent (FTE) in RES production was based on National Statistics Data on Environmental Activities (INE, 2012). For the biomass power generation units, a number of 220 direct employments were estimated based on a survey which allowed concluding that, in average, each power generation unit was responsible for the direct employment of 20 persons (PES, 2012). For the solid waste disposal (SWD) units 10 direct jobs were considered for each unit, according to a similar study (WVSWMB, 2011). For the mini-hydro power generation units and since most of these units operate automatically and with few maintenance requirements, we have considered 1.5 persons employed for each unit (see also ADENE, 2012). According to Amaral (2010) big hydro only employs permanently 85 people. For wind we have assumed according to EWEA (2009) that direct jobs only refer to O\&M which account for $11 \%$ of 800 . Photovoltaic (PV) is responsible for about 15 direct jobs in Amareleja unit (Acciona, 2012) and an average of 10 in other two PV units (Massada, 2009). For geothermal energy we have considered the same factor of 0.74 jobs per MW installed used in Jennejohn et al. (2009) 
and in case of ocean energy we have considered a factor of 0.32 jobs per MW installed used in Jennejohn et al. (2009) and EREC (2009). The remaining employments were allocated to biogas.

New I-O vectors have been constructed for each source: hydro, wind, PV, biomass (SWD, biomass and biogas) and geothermal. Figure 1 shows the intermediary inputs structure used to build these new I-O vectors, which was based on (Tourkolias and Mirasgedis, 2011) and on the Portuguese RES production share.

Figure 1 Cost structure allocation for the production of different RES types

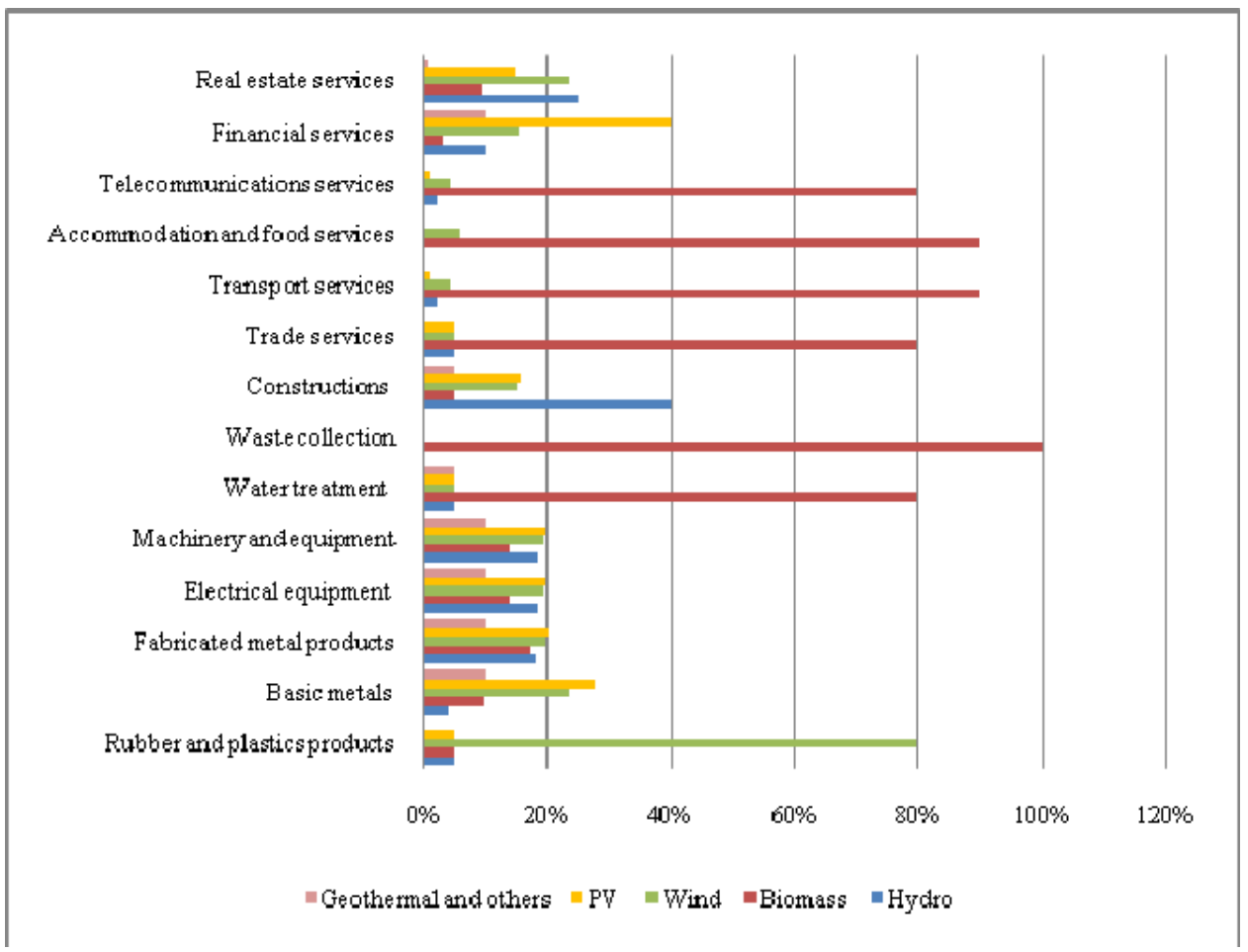

\subsection{Quantification of employment effects}

Figure 2 illustrates the estimated share of direct and total jobs (direct plus indirect jobs) for each RES type, according to the share of installed capacity for the base year of this study (2008).

Table 2 illustrates the estimated employment multipliers for the base year of this study (2008). Type I employment multipliers refer to the number of jobs directly and indirectly created per each job created for each RES industry. Type II employment multipliers concern the number of direct, indirect and induced jobs created per job created for each RES industry. According to the data herein presented for the year 2008, biomass contributes with the highest share $(50 \%)$ of direct jobs in the RES industry, followed by hydro (31\%), wind (11\%), PV (1\%) and, finally, geothermal and others (see Figure 2). If direct plus indirect jobs are considered for the base year of this study, the 
highest share of total jobs are attributed to biomass (37\%), followed by hydro (26\%), PV $(17 \%)$, wind (14\%) and geothermal (5\%). However, the RES sector with the highest job generation potential per job created (either according to Type I or Type II employment multipliers) is PV, followed by wind, geothermal, hydro and biomass (see Table 2). Figure 3 and Figure 4 allow assessing the contribution of each activity sector for job creation per RES sector and highlight once more the job generation potential of PV.

Particularly, for the PV units, the very high employment effects estimated might be mainly attributed to the high investment costs and the relatively low load factor that characterise this technology (Gülen, 2011).

A review of the literature will find numerous ways of measuring jobs created: jobs per annual MW installed, jobs per cumulative MW installed, manufacturing jobs per MW, person-year per MW, one-year jobs among others. In this study we will consider jobs per GWh and jobs per MW installed capacity. Typically these indicators are used to account for the number of permanent jobs created in the O\&M phase (see Table 3 and Table 4). The number of jobs computed per GWh and per MW of installed capacity computed considering the employment multipliers obtained in Table 2 and the RES production estimated for the time horizon of 2020, which was based on the RES installed capacity targets imposed by the Portuguese National RES Action Plan (NREAP, 2010) and considering the same rate of production of 2010 .

Figure 2 Estimated share of direct and total jobs in 2008

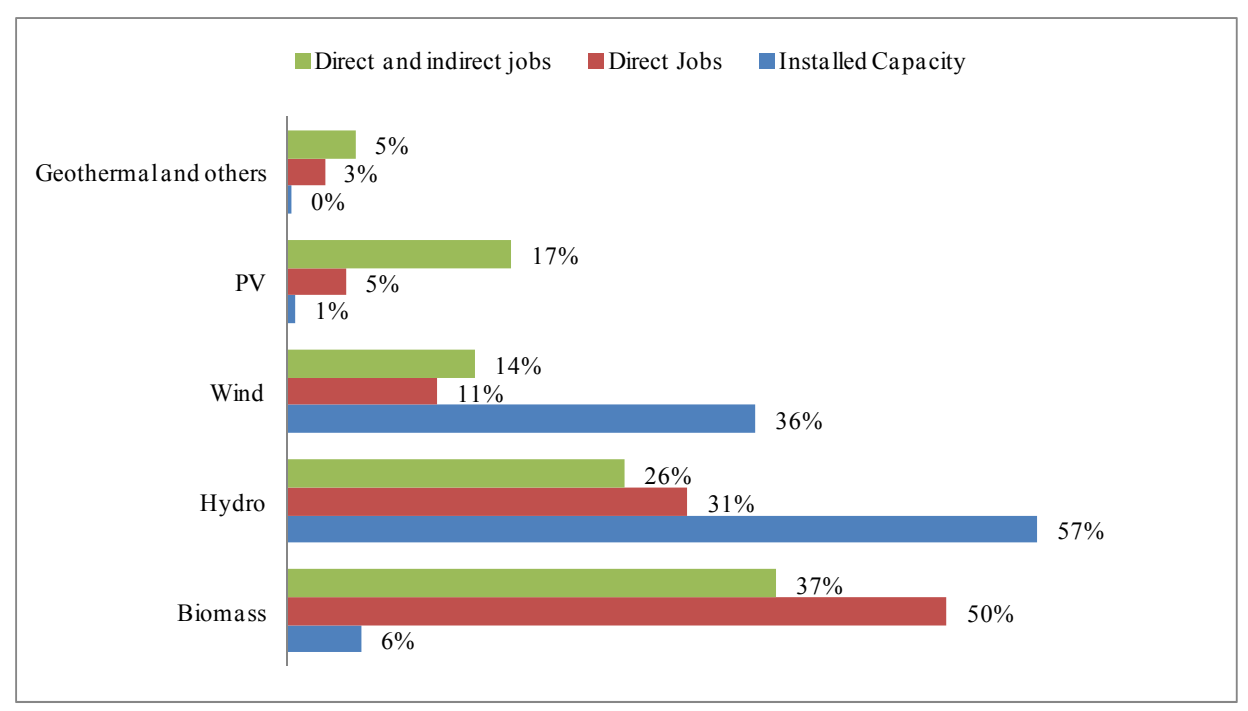

Table 2 Employment multipliers for each RES type

\begin{tabular}{lcccc}
\hline \multicolumn{5}{c}{ Type I: Employment multiplier } \\
\hline Hydro & Biomass & Wind & $P V$ & Geothermal and others \\
11,953 & 10,507 & 17,745 & 53,395 & 24,329 \\
\hline \multicolumn{5}{c}{ Type II: Employment multiplier } \\
\hline Hydro & Biomass & Wind & $P V$ & Geothermal and others \\
57,812 & 24,068 & 89,201 & 135,670 & 68,098 \\
\hline
\end{tabular}


Figure 3 Indirect and direct employment resulting from an increase of one additional FTE employment in RES industry

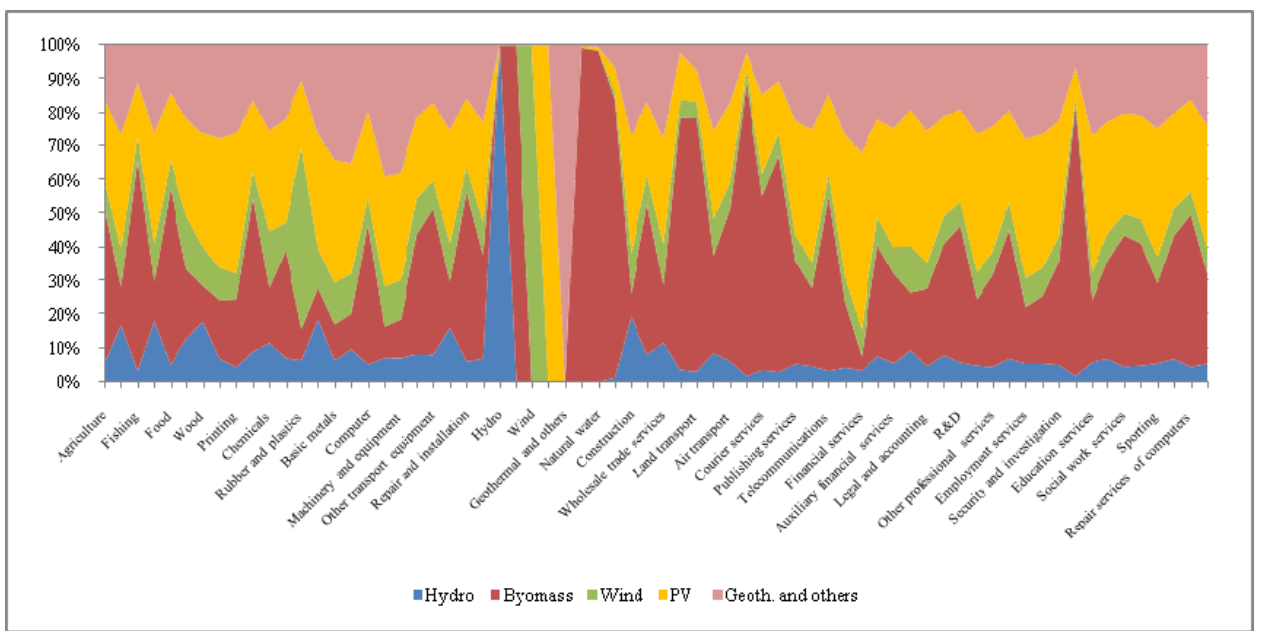

Figure 4 Indirect, direct and induced employment resulting from an increase of one additional FTE employment in RES industry

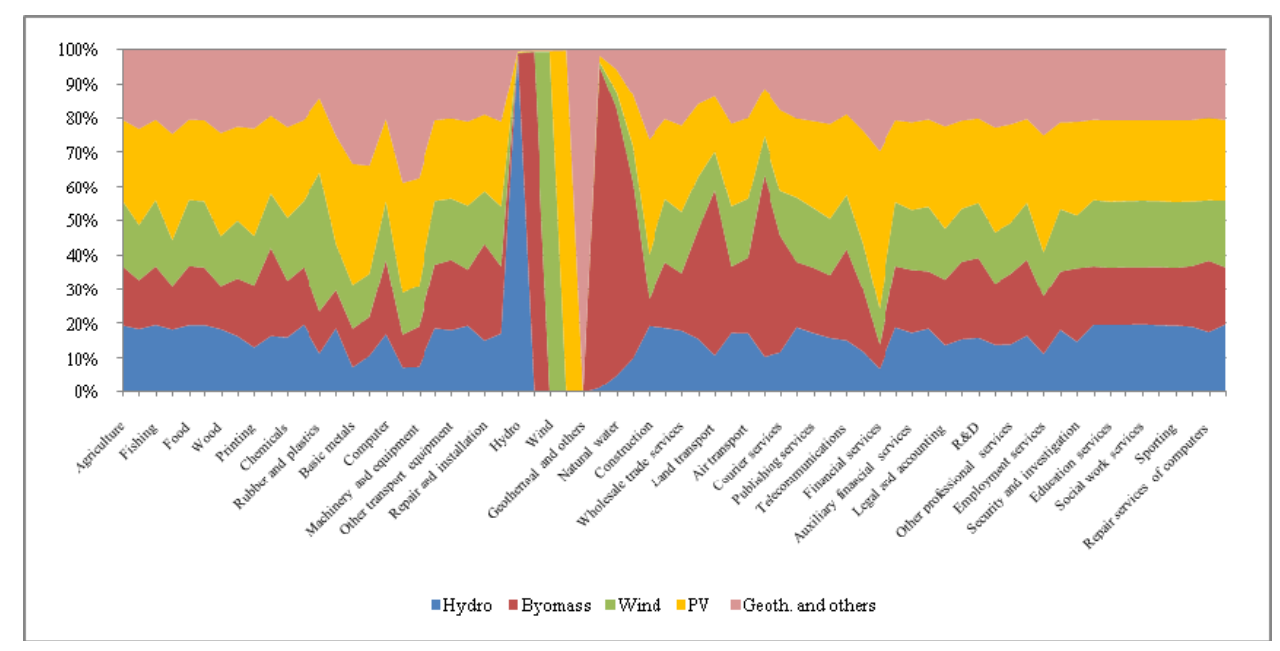

Table 3 Estimated employment effects related to the utilisation of RES technologies in Portugal for 2020 (in jobs/GWh)

\begin{tabular}{lccccc}
\hline Employment & Hydro & Biomass & Wind & $P V$ & Geoth. and others \\
\hline Direct & 0,032 & 0,069 & 0,015 & 0,921 & 0,123 \\
Indirect & 0,353 & 0,652 & 0,256 & 48,258 & 2,860 \\
Induced & 1,477 & 0,930 & 1,092 & 75,780 & 5,366 \\
Total & 1,862 & 1,650 & 1,364 & 124,959 & 8,349 \\
\hline
\end{tabular}


Table 4 Estimated employment effects related to the utilisation of RES technologies in Portugal for 2020 (in jobs/MW)

\begin{tabular}{lccccc}
\hline Employment & Hydro & Biomass & Wind & $P V$ & Geoth. and others \\
\hline Direct & 0,105 & 0,504 & 0,033 & 1,323 & 0,483 \\
Indirect & 1,151 & 4,794 & 0,549 & 69,311 & 11,269 \\
Induced & 4,817 & 6,838 & 2,342 & 108,838 & 21,143 \\
Total & 6,073 & 12,136 & 2,923 & 179,471 & 32,895 \\
\hline
\end{tabular}

Table 5 allows comparing some of the values herein attained for direct jobs in Jobs/GWh with the values obtained in different studies (see Huntington, 2009).

Table 5 Comparison of direct jobs attained with different studies

\begin{tabular}{lcc}
\hline Jobs $/$ GWh & Huntington (2009) & Portugal \\
\hline $\begin{array}{l}\text { Photovoltaics } \\
\text { (low) }\end{array}$ & 0,85 & 0,921 \\
Photovoltaics & 1,21 & \\
wind (low) & 0,08 & 0,015 \\
Wind & 0,32 & \\
Biomass (low) & 0,09 & 0,069 \\
Biomass & 0,32 & \\
\hline
\end{tabular}

The results of the analysis clearly show that the utilisation of all RES technologies in Portugal have significant employment implications (see Tables 3 and 4). Nevertheless, these results are characterised by significant uncertainties and one should consider them only as indicative approximations of the employment benefits associated with the development of RES in Portugal under these conditions. Therefore, in the next section a sensitivity analysis of the methodology herein followed will be performed through the use of distinct plausible coefficient settings.

\subsection{Uncertainty analysis}

As already mentioned previously, a critical issue for this kind of analysis is to what extent the manufacturing of the equipment will be undertaken domestically (even in this case parts of the equipment and some of the necessary raw materials will be imported) or this equipment will be almost entirely imported from abroad, influencing significantly the total level of the investment that will be spent domestically. Therefore, two opposite scenarios were quantitatively investigated, as explained in the subsequent section, in order to investigate the influence of some key parameters in the final results.

\subsubsection{Scenario A: basic RES equipment is domestically produced}

Scenario A assumes that the main elements of the necessary equipment for the development of the various RES projects will be produced in Portugal. As a result, basic RES equipment (either from rubber and plastics, basic metals, metal products, electrical equipment or machinery sectors) is considered to be domestically produced, thus internalising the import values on domestic production coefficients (see Figure 5). 
Figure 5 Coefficients of production with RES basic equipment entirely and non-entirely domestically produced (euro/euro)

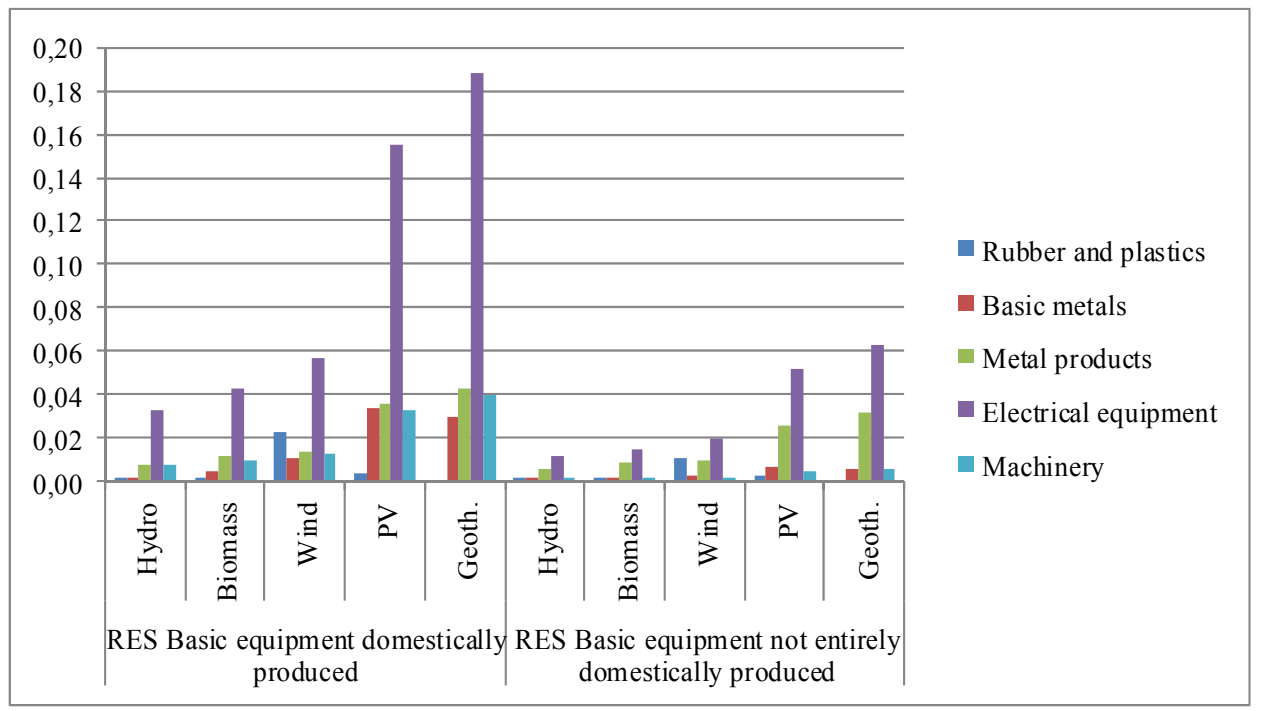

Table 6 Employment multipliers for each RES type

\begin{tabular}{lcccc}
\hline \multicolumn{5}{c}{ Type I: Employment multiplier } \\
\hline Hydro & Biomass & Wind & $P V$ & Geothermal and others \\
\hline 13,322 & 11,188 & 22,875 & 64,554 & 32,193 \\
\hline \multicolumn{5}{c}{ Type II: Employment multiplier } \\
\hline Hydro & Biomass & Wind & $P V$ & Geothermal and others \\
\hline 60,711 & 25,501 & 99,970 & 159,113 & 84,604 \\
\hline
\end{tabular}

As it would be expected, the employment multipliers with this new dataset suffer an increase (see Table 6). In fact, the highest increase in total jobs/GWh regarding the first scenario analysed (with no uncertainty handling) is obtained in geothermal $(24 \%)$, followed by PV (17\%), wind (12\%), biomass $(6 \%)$ and hydro (5\%) - see Table 7 and Table 8.

Table 7 Estimated employment effects related to the utilisation of RES technologies in Portugal for 2020 (in jobs/GWh)

\begin{tabular}{lccccc}
\hline Employment & Hydro & Biomass & Wind & $P V$ & Geoth. and others \\
\hline Direct & 0,032 & 0,069 & 0,015 & 0,921 & 0,123 \\
Indirect & 0,397 & 0,698 & 0,334 & 58,537 & 3,824 \\
Induced & 1,526 & 0,981 & 1,178 & 87,094 & 6,426 \\
Total & 1,955 & 1,748 & 1,528 & 146,551 & 10,373 \\
\hline
\end{tabular}


Table 8 Estimated employment effects related to the utilisation of RES technologies in Portugal for 2020 (in jobs/MW)

\begin{tabular}{lccccc}
\hline Employment & Hydro & Biomass & Wind & $P V$ & Geoth. and others \\
\hline Direct & 0,105 & 0,504 & 0,033 & 1,323 & 0,483 \\
Indirect & 1,294 & 5,137 & 0,717 & 84,073 & 15,068 \\
Induced & 4,978 & 7,217 & 2,526 & 125,087 & 25,318 \\
Total & 6,378 & 12,858 & 3,276 & 210,483 & 40,869 \\
\hline
\end{tabular}

The Portuguese national energy strategy 2020 (RCM, 29/2010) aims to attain the ambitious goals set in the government programme, 100,000 new jobs beyond the current 35,000 jobs and further developing the industrial cluster related with energy efficiency, creating 21,000 new jobs. However, the portfolio of policy instruments used by Portugal in its evolving strategy towards a greener economy will inevitably be reduced because of the economic and financial difficulties the country is facing, namely regarding the stringent goals associated with the public debt and deficit. In the beginning of 2012, the Portuguese government froze new renewable energy licenses (only hydro-electric power and cogeneration facilities were exempt). In this context, if NREAP 2020 targets are not met and the production and installed capacity are the same as in 2010 (according with the most recent data available for RES industry) by using the same job generation potential of Tables 7 and 8 we can conclude that these targets will only be achieved if induced jobs are explicitly considered (see Figure 6).

Figure 6 Total jobs created in RES sectors

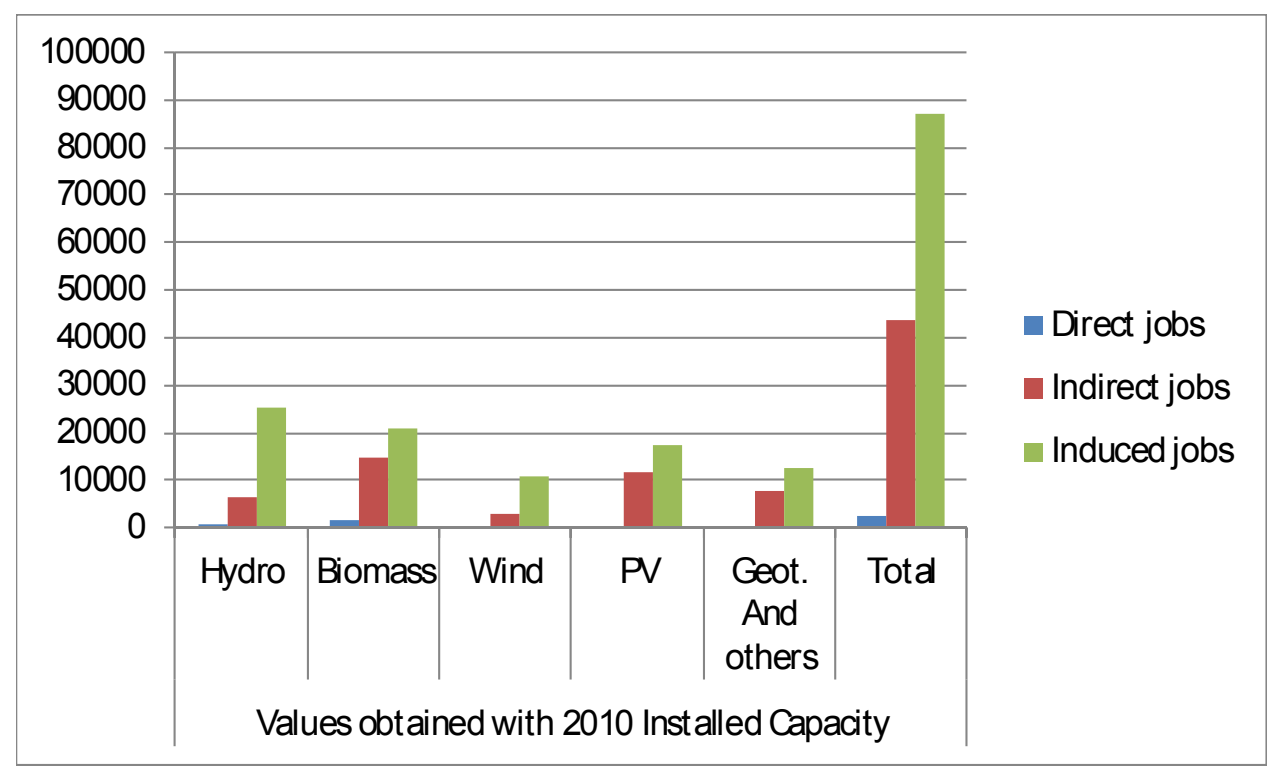

\subsubsection{Scenario B: basic RES equipment is imported}

Scenario B assumes that the main basic equipment necessary for the development of the various RES projects will be produced abroad. As a result, basic RES equipment (either 
from rubber and plastics, basic metals, metal products, electrical equipment or machinery sectors) is considered to be entirely imported.

Table 9 Estimated employment effects related to the utilisation of RES technologies in Portugal for 2020 (in jobs/GWh)

\begin{tabular}{lccccc}
\hline Employment & Hydro & Biomass & Wind & PV & $\begin{array}{l}\text { Geoth. and } \\
\text { others }\end{array}$ \\
\hline Direct & 0,032 & 0,069 & 0,015 & 0,921 & 0,123 \\
Indirect & 0,324 & 0,620 & 0,203 & 42,066 & 2,270 \\
Induced & 1,447 & 0,896 & 1,037 & 69,250 & 4,745 \\
Total & 1,803 & 1,585 & 1,255 & 112,237 & 7,138 \\
\hline
\end{tabular}

Table 10 Estimated employment effects related to the utilisation of RES technologies in Portugal for 2020 (in jobs/MW)

\begin{tabular}{lccccc}
\hline Employment & Hydro & Biomass & Wind & $P V$ & Geoth. and others \\
\hline Direct & 0,105 & 0,504 & 0,033 & 1,323 & 0,483 \\
Indirect & 1,058 & 4,561 & 0,436 & 60,417 & 8,943 \\
Induced & 4,718 & 6,693 & 2,222 & 99,459 & 18,696 \\
Total & 5,881 & 11,668 & 2,691 & 161,199 & 28,122 \\
\hline
\end{tabular}

Figure 7 illustrates the negative evolution of jobs/GWh per RES Sector if basic RES equipment is entirely produced abroad, regarding the business as usual scenario and Scenario A.

Figure 7 Average growth rate of jobs/GWh per RES Sector with Scenario B

\begin{tabular}{|c|c|c|}
\hline \multicolumn{3}{|l|}{$0 \%$} \\
\hline \multicolumn{3}{|l|}{$-5 \%$} \\
\hline \multicolumn{3}{|l|}{$-10 \%$} \\
\hline$-15 \%$ & \\
\hline \multicolumn{3}{|l|}{$-20 \%$} \\
\hline \multicolumn{3}{|l|}{$-25 \%$} \\
\hline \multirow{2}{*}{\multicolumn{2}{|c|}{$-35 \%$}} & \\
\hline & BAU & Scenario A \\
\hline Hydro & $-3 \%$ & $-8 \%$ \\
\hline - Biomass & $-4 \%$ & $-9 \%$ \\
\hline Wind & $-8 \%$ & $-18 \%$ \\
\hline $\mathrm{PV}$ & $-10 \%$ & $-23 \%$ \\
\hline Geot. And others & $-15 \%$ & $-31 \%$ \\
\hline
\end{tabular}

Once more, if one considers that NREAP 2020 targets are not met and the production and installed capacity are the same as in 2010 (according with the most recent data available 
for RES industry) by using the same job generation potential of Tables 9 and 10 we can conclude that these targets will only be achieved if induced jobs are explicitly considered (see Figure 8).

Figure 8 Total jobs created in RES sectors

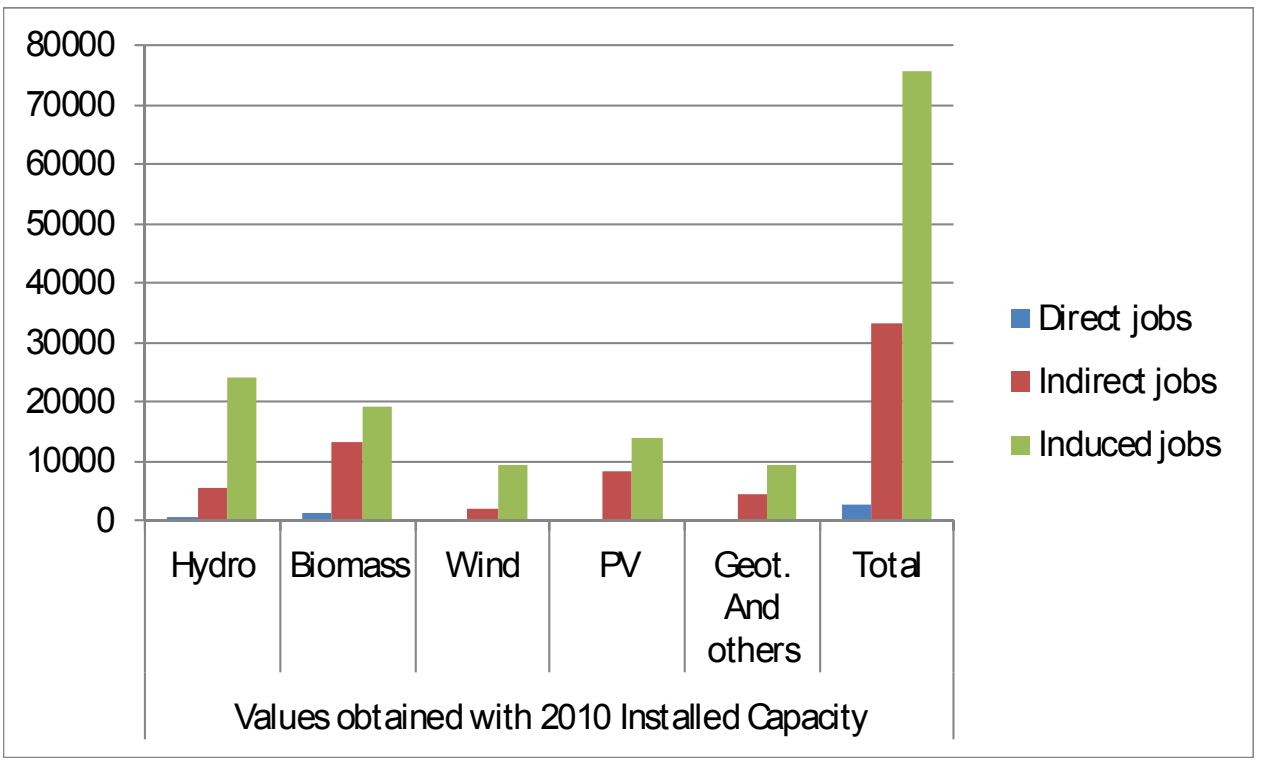

\section{Concluding remarks}

Rising unemployment is appearing as one of the most significant problems in many European countries, including Portugal. Currently, supporting employment through the adoption of effective policies is an expected priority for these countries.

In this study the direct, indirect and induced employment effects associated with the development and operation of five basic RES technologies were quantified and expressed in terms of jobs per GWh and jobs per MW installed capacity. The results highlight that the deployment of RES technologies have significant employment implications. According to the base case scenario, the most significant employment benefits were estimated for PV (with the highest job generation potential per job created), although biomass power plants were the ones with the highest share of direct plus indirect jobs $(37 \%)$.

It is important to underline that obtained results are site- and technology-specific, and therefore should not be generalised and exploited in other case studies. Their consistency was examined in the context of this paper through uncertainty analyses, highlighting distinct policy dimensions. The production of a significant part of the manufacturing activities domestically is an ideal prerequisite for maximising the positive socio-economic effects of the development of RES in the Portuguese economy, albeit of some unrealistic nature. Focusing on the NREAP targets it is possible to conclude that they will only be achieved if induced jobs are explicitly considered, what allows us to reinforce their relevant ambitious nature. 
Besides the I-O approach, other methodologies can be developed to analyse alternative scenarios that can show net job gains over a certain period of time but these are based on aggressive and unrealistic assumptions of continuous and fast technological innovation, rapid progression of economies of scale, global implementation of similar green policies, adoption of protectionist measures such as tariffs or local content requirements and others.

In what concerns renewables, although it stands reasonable to expect improvements in technology and cost structure in the future, it is difficult to predict the development path that can be included in modeling exercises. These technologies have benefited from subsidies, tax incentives and mandates to gain market share (some more than others) and with direct, indirect and induced consequences to the potential of job creation according to each RES type. As seen in previous sections, some authors argue that pushing aggressively to increase the share of these technologies will cost large sums of money and will increase cost of energy to society, negatively impacting purchasing power, employment and GDP.

Work is currently under way which allows showing that the overall Portuguese energy policies on RES have benefits ranging from lower emissions to enhanced energy security, albeit at different levels for different technologies. However, net job creation resulting directly from these policies cannot be straightforwardly defended as another benefit of investing in these technologies.

\section{Acknowledgements}

This work has been supported by project PEst-C/EEI/UI0308/2011 and has been framed under the Energy for Sustainability Initiative of the University of Coimbra and supported by the R\&D Project EMSURE Energy and Mobility for Sustainable Regions (CENTRO 070224 FEDER 002004).

\section{References}

Acciona (2012) 'Amareleja photovoltaic solar unit', Worldwide Reference for the Development of Renewable Energies (in Portuguese) [online] http://www.accionaenergia.es/media/315790/Central\%20solar\%20fotovoltaica\%20de\%20Amareleja_Portugu\%C 3\%A9s.pdf (accessed 12 March 2012).

ADENE (2012) Re. New. Able. [online] http://www.renewable.pt/pt/RE/Paginas/agua.aspx (accessed 12 March 2012).

Alvarez, G.C., Jara, R.M., Juliá, J.R.R. and Bielsa, J.I.G. (2010) 'Study of the effects on employment of public aid to renewable energy sources', Procesos De Mercado, Universidad Rey Juan Carlos, Primavera, Vol. VII, No. 1.

Amaral, L.M. (2010) 'Employment and renewables', Expresso (in Portuguese) [online] http://expresso.sapo.pt/o-emprego-nas-renovaveis=f574105 (accessed 12 March 2012).

Amorim, F., Martins, V. and Silva, P. (2010) 'A new perspective to account for renewables impacts in Portugal', Energy Market (EEM), 2010 7th International Conference on the European IEEExplore, 8p.

Caldés, N., Varela, M., Santamaría, M. and Sáez, R. (2009) 'Economic impact of solar thermal electricity deployment in Spain', Energy Policy, Vol. 37, No. 1, pp.1628-1636.

Ciaschini, M. (1988) 'Input-output analysis: an introduction', in M. Ciaschini (Ed.): Input-Output Analysis - Current Developments, Chapter 1, pp.1-16, Chapman and Hall, London. 
del Rio, P. and Burguillo, M. (2008) 'Assessing the impact of renewable energy deployment on local sustainability: towards a theoretical framework', Renewable and Sustainable Energy Reviews, Vol. 12, No. 9, pp.1325-1344.

DGEG (2009) Renováveis. Estatísticas rápidas, nº 55/56, Setembro/Outubro.

Dias, A. and Domingos, E. (2011) Department of Foresight and Planning, Input-Output Matrices Integrated Systems for Portugal (in Portuguese).

Duchin, F. and Steenge, A. (1999) 'Input-output analysis, technology and the environment', in. J. van den Bergh (Ed.): Handbook of Environmental and Resource Economics, Part IX, Chapter 68, pp.1037-1059, Edward Elgar, Cheltenham.

EREC (2009) 'Working for the climate. Renewable energy and greenjob revolution', [online] http://www.greenpeace.org/international/Global/international/planet-/report/2009/9/workingfor-the-climate.pdfS (accessed 12 March 2012).

EU (2008) Directive Proposal 2008/0016 Relative to the Promotion of the Utilization of Renewable Energy Resources [online] http://eur-lex.europa.eu/LexUriServ/LexUriServ.do?uri=COM: 2008:0019:FIN:PT:PDF (accessed 12 March 2012).

European Commission (1997) Communication from the Commission 'Energy for the future: renewable sources of energy', White Paper for a Community Strategy and Action Plan.

European Commission (2011) Communication from the Commission to the European Parliament and the Council - Renewable Energy: Progressing Towards the 2020 Target, COM, 31 final. Brussels.

European Parliament (2009) Directive 2009/28/EC of the European Parliament and of the Council of 23 April 2009 on the promotion of the use of energy from renewable sources and amending and subsequently repealing, Directives 2001/77/EC and 2003/30/EC, L140/16, Brussels.

EWEA (2009) Wind at work. Wind energy and job creation in the EU [online] http://www.ewea.org/fileadmin/ewea_documents/documents/publications/Wind_at_work_FIN AL.pdf (accessed 12 March 2012).

Gay, P. and Proops, J. (1993) 'Carbon-dioxide production by the UK economy: an input-output assessment', Applied Energy, Vol. 44, No. 2, pp.113-130.

Government XVIII (2009) Program from the XVIII Constitutional Government of Portugal 20092013.

Gülen, G. (2011) Defining, Measuring and Predicting Green Jobs, Copenhagen Consensus Center [online] http://www.copenhagenconsensus.com/Default.aspx?ID=1542.http://www.dpp.pt/ Lists/Pesquisa\%20Avanada/Attachments/3230/Matrizes_2008.pdf (accessed 12 March 2012).

Henriques, C. and Silva, P.P. (2011) 'Assessing the conflicting interactions of employment with sustainable development', in Proceedings of the SDEWES2011 6th International Conference on Sustainable Development of Energy, Water and Environment Systems, Dubrovnik.

Hughes, G. (2011) 'The myth of green jobs', The Global Warming Foundation Report No. 3, London.

Huntington, H. (2009) 'Creating jobs with 'green' power sources', USAEE Dialogue, March, Vol. 17, No. 1 [online] http://emf.stanford.edu/files/pubs/22522/OP64.pdf (accessed 12 March 2012).

INE (2012) National Statistics Office, People serving entities producing environmental goods and services for each economic activity, according to sex and occupation and functions performed in the environmental field (in Portuguese) [online] http//:www.ine.pt (accessed 12 March 2012).

Jennejohn, D., Blodgett, L. and Gawell, K. (2009) Geothermal Energy and Jobs, Geothermal Energy Association [online] http://www.geo-energy.org/pdf/Geothermal_Energy_and_Jobs_ Issue_Brief.pdf (accessed 12 March 2012).

Kammen, D.M., Kapadia, K. and Fripp, M. (2004) 'Putting renewables to work: how many jobs can the clean energy industry generate?', Report of the Renewable and Appropriate Energy Laboratory, University of California, Berkeley, April (corrected January 2006). 
Lehr, U., Nitsch, J., Kratzat, M., Lutz, C. and Edler, D. (2008) 'Renewable energy and employment in Germany', Energy Policy, Vol. 36, pp.108-117.

Leontief, W. (1986) 'Input-output analysis', in. W. Leontief (Ed.): Input-Output Economics, 2nd ed., Chapter 2, pp.19-40, Oxford University Press, New York.

Massada, J. (2009) 'Third photovoltaic solar unit in Ferreira do Alentejo already operating', Jornal de Ciência Tecnologia e Empreendedorismo, (in Portuguese) [online] http://www.cienciahoje.pt/index.php?oid=34949\&op=all (accessed 12 March 2012).

Michaels, R. and Murphy, R.P. (2009) Green Jobs: Fact or Fiction?, Institute for Energy Research, Houston, Texas, January.

Miller, R. and Blair, P. (1985) Input-output Analysis: Foundations and Extensions, Prentice Hall, New Jersey.

Morriss, A.P., Bogart, W.T., Dorchak, A. and Meiners, R.E. (2009) Green Jobs Myths, Case Western Reserve University Research Paper Series No. 09-15, March.

National Renewable Energy Action Plan (NREAP) (2010) [online] http://ec.europa.eu/energy/ renewables/transparency_platform/doc/national_renewable_energy_action_plan_portugal_en. pdf (accessed 12 March 2012).

OECD (2011) Towards Green Growth, OECD, Paris, May.

PES (2012) Portuguese Endogenous Energies [online] http://e2p.inegi.up.pt/index.asp (accessed 12 March 2012).

RCM (29/2010) [online] http://www.pofc.qren.pt/ResourcesUser/Legislacao/20100504_RCM_ 29_2010.pdf (accessed 12 March 2012).

Tourkolias, C. and Mirasgedis, S. (2011) 'Quantification and monetization of employment benefits associated with renewable energy technologies in Greece', Renewable and Sustainable Energy Reviews, Vol. 15, pp.2876-2886.

UNEP (2011) Towards a Green Economy: Pathways to Sustainable Development and Poverty Eradication [online] http://www.unep.org/greeneconomy/ (accessed 12 March 2012).

Wei, M., Patadia, S. and Kammen, D.M. (2010) 'Putting renewable and energy efficiency to work: how many jobs can the clean energy industry generate in the US?', Energy Policy, Vol. 38, pp.919-931.

West Virginia Solid Waste Management Board (WVSWMB) Economic Impact of Municipal Solid Waste Management in West Virginia [online] http://www.state.wv.us/swmb/RMDP/ 2011StatePlan/Chapter9.pdf (accessed 12 March 2012). 